\title{
Physical Science Teachers' Insights into Pedagogical and Content Knowledge, and the Nature of Support of an ACE In-service Programme
}

\author{
Doras Sibanda \\ Tabitha Grace Mukeredzi
}

\begin{abstract}
This study was designed to gain insights into physical science teacherstudents' pedagogical knowledge, understanding of science concepts and the nature of support that they received during an in-service developmental programme. Understanding the experiences and learning gained during the programme can inform the design of future courses. The study is located within an interpretive paradigm that employs a qualitative approach to data collection and analysis. Participants $(n=156)$ were selected by convenience sampling from teachers on an in-service Advanced Certificate in Education programme. Data were collected towards the end of the proramme through a questionnaire administered to 211 in-service teachers and eight teachers were interviewed. The study identified three critical aspects gained during the programme: content knowledge, teaching strategies and confidence. The findings also reinforce the need for institutions of higher learning to design programmes that provide the appropriate level of support: material, emotional or both for all teachers on in-service programmes.
\end{abstract}

Keywords: ACE Physical Science, learning, support, teacher-students, programme 


\section{Background of the Study}

The Advanced Certificate in Education programme, which was offered at several South African universities, was born out of recognition that although teacher qualifications had improved, the majority of teachers were not sufficiently equipped to address the educational needs of a growing democracy in the twenty-first century (Department of Education (DoE) 2006).

In the post-apartheid period, the South African Government embarked on several initiatives to achieve education quality; among them, addressing the skills deficit arising from inadequate training policies of the previous government (Council of Higher Education (CHE) 2010). For instance, the South African national performance in science and technology lagged far behind or was, in many instances, worse than in economically poorer countries. Poor teacher quality has been blamed for poor learner performance in benchmarked tests in mathematics (CHE 2010; Spaull 2013). In this regard, the supply of mathematics and science teachers was inadequate and the teachers were poorly trained (Taylor 2009). The Department of Higher Education and Training (DHET) indicated that these inadequacies underpinned the need for improving the quality of teacher education in the country in order to address learner underperformance (DHET 2015). Accordingly, the government initiative to provide 'more teachers' and 'better teachers' was driven by the conviction that good teachers are indispensable drivers of good quality education (DoE 2006; Robinson \& Latchem 2002). Quality education to fulfill a country's needs depends primarily on teachers' academic qualifications and pedagogical skills (Chung 2005).

With this in mind, the South African government launched teacher in-service education and training programmes (CHE 2010). The suite of such programmes included both short courses and full credit bearing qualifications, such as the Further Diploma in Education (FDE), which offered teachers opportunities for re-skilling or upgrading their initial teaching qualifications through a three-year teaching diploma (CHE 2010; Parker, 2004). The FDE was designed with several advantages for teachers: they could re-skill, have avenues opened for new career paths, change their teaching specialization and by upgrading their initial qualification from an $\mathrm{M}+3$ to an $\mathrm{M}+4$ gain access to higher degree studies, such as a BEd (Hons) (CHE 2010; Parker 2004).

When the Norms and Standards for Educators policy was introduced, the FDE was renamed Advanced Certificate in Education (ACE) (DoE 2000). 
The ACE became a multi-purpose qualification for teacher upgrading or reskilling, and for enabling access to higher-level programmes (CHE 2010). The programme was a $120 \mathrm{NQF}$ credit, Level 6 qualification. It has been described as 'further specialised subject / learning area / discipline / phase competence, or a new subject specialisation in one or more of the roles as an advanced study. The qualification was intended to 'cap' an initial or general teaching qualification, through which graduates were able to proceed with studies at NQF Level 7' (CHE 2010:106). The ACE was therefore, conceived as a continuing professional education programme designed to equip teachers with skills, competencies, aptitudes and proficiencies, or to allow change of their career path to new teaching roles (DoE 2006). Further, the key objective of the South African Education Revised National Curriculum Statement (RNCS) was to develop knowledge, skills, and values of learners (DoE 2006), which influenced goals of all staff development programmes designed for teachers.

The prerequisite for admission into the ACE programme was a threeyear teacher diploma; bachelor's degree in education (BEd) or, a postgraduate certificate in education (PGCE) for those-in Educational Management (CHE 2010). The physical science ACE programme, introduced in response to poor teacher quality in science (Spaull 2013) was offered to candidates who already possessed an NQF Level 6 teacher qualification, and who were already teaching physical science at high school.

\section{The ACE Physical Science (ACEPS)}

The ACE qualification in Physical Science (ACEPS) was one of the subject specialization programmes offered by one South African university within the suite of ACE programmes launched by government. The objectives of the ACEPS were to develop teachers' content knowledge and practical skills for teaching in the Further Education and Training phase (FET). The programme thus required teachers to study two professional modules and six content modules. The content modules comprised three 16-credit chemistry modules and three 16-credit physics modules.

The programme was delivered through mixed mode at the university and at satellite learning centres in KwaZulu-Natal province. Students interacted with learning materials on their own, and attended face-to-face contact sessions, facilitated by tutors. The contact sessions of seven hours per 


\section{Doras Sibanda \& Tabitha Grace Mukeredzi}

day, for each module were run over eight days per semester, generally over weekends and school holidays.

Pedagogical approaches used during the face-to-face encounters involved student-centred interactive strategies, including pair work, group work, individual engagements, research and presentations. The teacherstudents each received two physical science textbooks as well as guides for their self-study. The latter clearly outlined instructions on activities and preparation for subsequent sessions. To enable access to the university library and laboratories, the practical components for the content modules were offered only at the university.

The teacher-students were each issued with a science kit. The kits contained equipment and instructions for teaching FET Physical Science practicals. While still at university, before taking the kits away, the in-service teachers were given time to go through the instructions therein, and practice the experiments, carrying out all activities under supervision. They were also given time for questions and reflections.

\section{Rationale for the Study}

The contribution of education and training to a country's economic development has been documented (see for example Bernstein 2011; Mahlangu \& Pitsoe 2013). Acquisition of knowledge, skills and competencies through education is vital for citizens' effective performance in any field, thereby contributing to national economic and social development. However, given that good teachers are essential drivers for quality education, such acquisition needs an education system with teachers who possess the necessary knowledge, skills, competences, and dispositions for effective curriculum delivery (DoE 2006; Robinson \& Latchem 2002). The launch of the ACE programme was prompted by awareness of teachers' poor knowledge of the content and skills needed for effective discharge of teaching duties, which was reflected in poor learner performance particularly in mathematics and science (Spaull 2013). Hence, through the ACE upgrading programme offered in various specializations in the country, the goal of the government was to address the content and skills deficit among teachers (Council of Higher Education (CHE) 2010; Robinson \& Latchem 2002; Spaull 2013).

Despite the overall aim of the ACE programmes being to address the gap in both subject knowledge and pedagogical skills of practicing teachers, 
not much research has been carried out to explore the learning that these inservice teachers received on the developmental programmes. Aluko (2009) investigated the impact of the ACE programme on the professional practice of graduates and found that the program was beneficial to graduates' personal development, professional practice, schools, learners, and colleagues. On the other hand, Stears, James and Good (2012) explored professional identities of physical science teachers also on the ACE and found that very little conceptual change had occurred through the programme. However, these two studies while they were on the ACE programme, investigated different aspects from the current study. This study therefore sought to understand their learning and so contribute to knowledge on this aspect.

\section{Research Question(s)}

1. What do ACE Physical Science teachers say they learnt through the Physical Science programme?

2. What kind of support did the teacher-students receive during the programme?

\section{Theoretical Framework}

This research, which investigated the kinds of knowledge that the ACE Physical Science teacher-students learnt, is informed by concepts related to teacher knowledge. Shulman (1987) categorized professional knowledge for teaching into seven domains, the first four of which are relevant to this study:

1. Content knowledge

2. General pedagogical knowledge

3. Pedagogical content knowledge

4. Curriculum knowledge

5. Knowledge of learners and their characteristics

6. Knowledge of educational contexts e.g. schools and wider communities

7. Knowledge of educational ends, purposes and values

The first four categories, content knowledge (CK), general pedagogical knowledge (GPK), pedagogical content knowledge (PCK) and curriculum 


\section{Doras Sibanda \& Tabitha Grace Mukeredzi}

knowledge, are often regarded as the building blocks of the knowledge domains (Cogill 2008; Grossman 1990). Shulman defined PK as the broad principles and strategies of classroom management and organization that go beyond subject matter. Thus, some general PK may be gained from practice. Content knowledge (CK) is 'the knowledge, understanding, skill and dispositions that are to be learned by school children' (Shulman 1987:8-9). Curriculum knowledge constitutes the teacher's 'tools of the teaching trade', for example knowledge of learning materials and any classroom documentation. As an amalgam of content and pedagogy, PCK is exclusive to the teaching profession.

Since Shulman had identified the seven domains many other models and theories of teacher professional and pedagogical knowledge and skills have been developed (Cogill 2008). Some scholars criticised Shulman's (1987) model for not reflecting the in-depth linkages between domains and their implementation, and how these would shape teachers' pedagogy (Banks, Leach and Moon 1999; Sai 2008). In particular, Sai asserted that definitions of some knowledge types, such as curriculum knowledge and pedagogical content knowledge, need further expansion, and argued that using content knowledge, as a starting point for teachers or prospective teachers may be inappropriate in situations where they enter teacher education with previous experiences and specialist subject knowledge (Sai 2008).

With this background, Banks et al. (1999) re-conceptualized and extended Shulman's model. Their model, illustrated in Figure 1 below, comprises four domains: GPK, CK, school knowledge (curriculum knowledge) and personal constructs. The GPK, CK, PCK and Curriculum Knowledge are closely linked to teachers' values, beliefs and experiences. A major difference between this model and that of Shulman's relates to the dynamic nature of teacher knowledge. Shulman (1987), on the one hand, viewed teacher knowledge as external and fixed, not constantly changing, although it could be improved through the teacher's own on-going learning. On the other hand, Banks et al. (1999) argue that a teachers' knowledge is derived from their Subject knowledge, Pedagogical knowledge and School knowledge.

Subject knowledge corresponds with Shulman's Content Knowledge (CK). School knowledge subsumes both Shulman's Curriculum Knowledge and his PCK. Thus, school knowledge refers to how CK is taught in schools and includes understanding the processes necessary for transforming knowledge to make it accessible to learners. As does McNamara (1991), Banks et al. do not 
regard School knowledge as an intersection of Shulman's CK and PK. Instead, they think that school knowledge involves firstly, mastery of school curricula in a subject, and then what happens at the intersection of school knowledge with the curriculum leads to teachers creating their own PCK (Cogill 2008). Banks et al. (1999) suggest that such learning is dynamic, continuously being interpreted and re-interpreted at different levels.

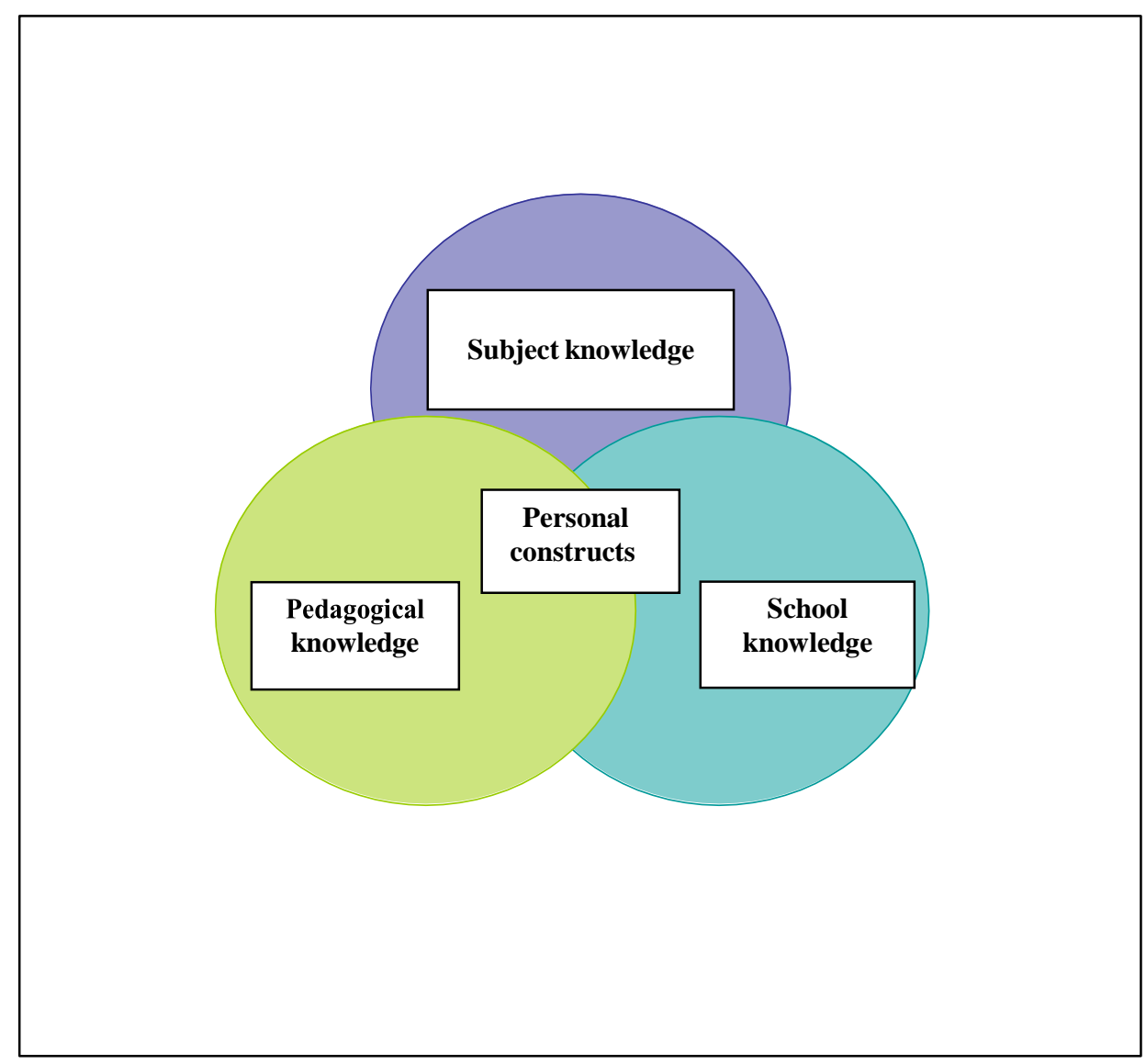

Figure 1: Teachers' professional knowledge (Banks et al. 1999: 94). 
Pedagogical knowledge is similarly constantly changing and closely integrated with CK and PCK. Central to Banks et al.'s (1999) model is Personal constructs, which are a teacher's 'complex amalgam of past knowledge, learning experiences, personal views of what constitutes good teaching, and belief in the purposes of the subject' (Cogill 2008:6). Thus, a teacher's personal constructs emanate from their experiences, and underpin their professional knowledge and these are continuously being re-evaluated throughout a teacher's career (Banks et al. 1999).

\section{Methodology}

This study sought to understand the learning and support that the ACE Physical Science students had received through the programme. The study is located within an interpretive paradigm, which led to a qualitative approach of generating data, firstly through a questionnaire, with both closed and openended questions, and then by interviews. Reeves and Hedberg (2003:32) note that the 'interpretivist paradigm stresses the need to put analysis in context'. Hence, understanding the world as it is through the subjective experiences of individuals directs the interpretive paradigm, and this understanding attempts to explain the subjective reasons and meanings that lie behind social action. Grover (2004) argues that qualitative research allows researchers to understand people has lived experiences and provides the stories behind the numbers. This study aimed to understand the learning and support received, according to the participants' perspectives.

Convenience sampling was used. All the in-service teachers who were enrolled in the programme participated in the study. Hence, sampling was based on accessibility of participants. According to Creswell (2014), a convenience sample draws largely on participants' convenient accessibility and willingness to participate. While a convenience sample has limitations in terms of accuracy, it can nevertheless, provide useful insights into the situation under study. Therefore, notwithstanding that results should not be overgeneralized they could be applicable to similar contexts and populations.

\section{Data Generation}

The questionnaire used for this study was developed by the ACE programme leaders to generate data as part of a larger project; that is, gathering information 
to build a strong argument supporting teacher development through Continuing Education. The institution's higher degrees and ethics committee granted ethical clearance for this study in 2011 as part of the larger project, which investigated all in-service teachers on the ACE programme across all specialisations. For the current study, we administered the questionnaire to 211 ACEPS in-service teachers at or towards the end of their final year of study. There were 156 questionnaires completed and returned. The questionnaire required the teacher-students to indicate their experiences relating to tutors, learning centres, university communication and the kinds of knowledge gained from the programme that they thought had improved their teaching. Eight teachers who had indicated interest in being interviewed and who taught at schools that were close by were subsequently interviewed in order to gain deeper understanding of their experiences and the support they had received from the university.

\section{Data Analysis}

In qualitative research data, analysis involves working with the data: organizing them, breaking them down, synthesizing and searching for patterns, discovering important aspects, and what is to be learned from the aspects, and deciding what you will tell others (Creswell 2014). In the survey teachers responded to statements using a Likert-type scale of strongly disagree, disagree, neutral, agree and strongly disagree. In the analysis we aggregated strongly disagree with disagree as 'disagree' and strongly agree with agree as 'agree'. The results in Table 1 represent that aggregation. For the interviews, both researchers read each participant's interview transcript repeatedly. Subsequently the teachers' responses were coded using a framework suggested by Banks et al. (1999). The coding focused on the four aspects of their model: GPK, CK, personal constructs (attitude, confidence and experience), and school knowledge. These aspects were then coded as Nodes using computer software Nvivo 11. Data were analyzed using the wizard query search matrix. The matrix results were then exported to Microsoft Excel for further analysis. Findings from the Survey and interviews are presented and discussed together.

\section{Results}

The results in Table 1 represent the responses from the survey questionnaire, aggregated as described above. The results are reported as percentages, to the 
nearest whole number. DP is Duly Performed certificate, which students earn through continuous assessment, and without which they would not be allowed to write the final examination in the module.

Table 1 Percentage of Physical science ACE students who disagreed, were neutral or agreed with each statement [n 156]

\begin{tabular}{|c|c|c|c|c|}
\hline Questions & & Respor & ses & \\
\hline $\begin{array}{l}\text { What can you say about the } \\
\text { tutors on the programme? }\end{array}$ & $\begin{array}{c}\text { No } \\
\text { response }\end{array}$ & Disagree & Neutral & Agree \\
\hline knew the content very well & 4.49 & 2.56 & 16.67 & 76.28 \\
\hline $\begin{array}{l}\text { were able to explain the content } \\
\text { well }\end{array}$ & 2.56 & 1.28 & 17.95 & 78.21 \\
\hline were always well prepared & 1.92 & 4.49 & 25.00 & 68.59 \\
\hline $\begin{array}{l}\text { were considerate and empathetic } \\
\text { to our situation }\end{array}$ & 7.05 & 1.28 & 17.31 & 74.36 \\
\hline treated us as adults and colleagues & 1.92 & 1.28 & 3.85 & 92.94 \\
\hline $\begin{array}{l}\text { What can you say about the } \\
\text { learning centre? } \\
\text { the conditions were good for } \\
\text { learning }\end{array}$ & 1.92 & 8.34 & 17.31 & 72.43 \\
\hline there was sufficient resources & 0.64 & 12.18 & 27.56 & 59.61 \\
\hline $\begin{array}{l}\text { the university appointed centre } \\
\text { manager was available and useful }\end{array}$ & 3.21 & 11.54 & 28.21 & 57.05 \\
\hline $\begin{array}{l}\text { the centre owner/manager was } \\
\text { welcoming }\end{array}$ & 1.92 & 23.08 & 25.00 & 50.00 \\
\hline we felt welcome at the centre & 0.00 & 6.41 & 31.41 & 62.18 \\
\hline $\begin{array}{l}\text { What can you say about } \\
\text { communication by university? } \\
\text { the process of the calculation of } \\
\text { the DP }\end{array}$ & 0.00 & 16.03 & 14.10 & 69.87 \\
\hline DP appeal process & 1.92 & 18.59 & 42.95 & 36.54 \\
\hline Special requests & 4.49 & 12.82 & 28.85 & 53.85 \\
\hline timetables & 0.00 & 5.77 & 14.10 & 80.13 \\
\hline $\begin{array}{l}\text { Feedback on tests and } \\
\text { assignments }\end{array}$ & 0.00 & 4.49 & 8.97 & 86.54 \\
\hline registration details & 0.00 & 14.74 & 21.79 & 63.46 \\
\hline examination results & 0.00 & 8.98 & 11.54 & 79.49 \\
\hline
\end{tabular}




\begin{tabular}{|c|c|c|c|c|}
\hline \multicolumn{5}{|l|}{$\begin{array}{l}\text { To what extent has your } \\
\text { participation in the ACEPS } \\
\text { improved your Teaching } \\
\text { Practice. }\end{array}$} \\
\hline $\begin{array}{l}\text { my content knowledge has } \\
\text { improved }\end{array}$ & 0.64 & 0.00 & 1.92 & 97.43 \\
\hline $\begin{array}{l}\text { my teaching strategies have } \\
\text { improved }\end{array}$ & 1.92 & 0.00 & 10.26 & 88.15 \\
\hline $\begin{array}{l}\text { my confidence as an PS teacher } \\
\text { has increased }\end{array}$ & 2.56 & 0.00 & 7.69 & 89.74 \\
\hline $\begin{array}{l}\text { The } P S \text { results of my learners } \\
\text { have improved. }\end{array}$ & 5.77 & 1.28 & 28.85 & 64.41 \\
\hline \multicolumn{5}{|l|}{$\begin{array}{l}\text { My studies were made easier } \\
\text { because }\end{array}$} \\
\hline $\begin{array}{l}\text { the materials (guides) were } \\
\text { readable, clear and useful }\end{array}$ & 1.28 & 5.77 & 27.56 & 65.38 \\
\hline the tutors were supportive & 1.28 & 1.92 & 10.90 & 85.90 \\
\hline the tutors were knowledgeable & 1.28 & 3.85 & 12.82 & 82.05 \\
\hline $\begin{array}{l}\text { link between was taught and } \\
\text { assessed }\end{array}$ & 1.28 & 14.75 & 30.77 & 53.20 \\
\hline $\begin{array}{l}\text { the other students in my class } \\
\text { were supportive and helpful }\end{array}$ & 5.77 & 0.00 & 14.10 & 80.12 \\
\hline \multicolumn{5}{|l|}{$\begin{array}{l}\text { My studies were made easier } \\
\text { because }\end{array}$} \\
\hline I had a supportive family network & 1.28 & 13.47 & 31.41 & 53.85 \\
\hline $\begin{array}{l}\text { I had support from my school } \\
\text { management and colleagues }\end{array}$ & 1.28 & 25.64 & 35.26 & 37.82 \\
\hline $\begin{array}{l}\text { I found the contact sessions to be } \\
\text { well paced and not too intensive }\end{array}$ & 1.28 & 25.00 & 27.56 & 46.15 \\
\hline I had sufficient time to study & 1.28 & 30.77 & 37.18 & 30.77 \\
\hline $\begin{array}{l}\text { The centre is not very far away } \\
\text { from me. }\end{array}$ & 1.28 & 33.98 & 19.23 & 45.51 \\
\hline
\end{tabular}

Findings from interviews are presented in Figure 1 below, as a graph of the frequency of utterance for each of the different aspects. The coding involved the utterances and, as such, the frequency represents the number of times, the participants mentioned such a response. 


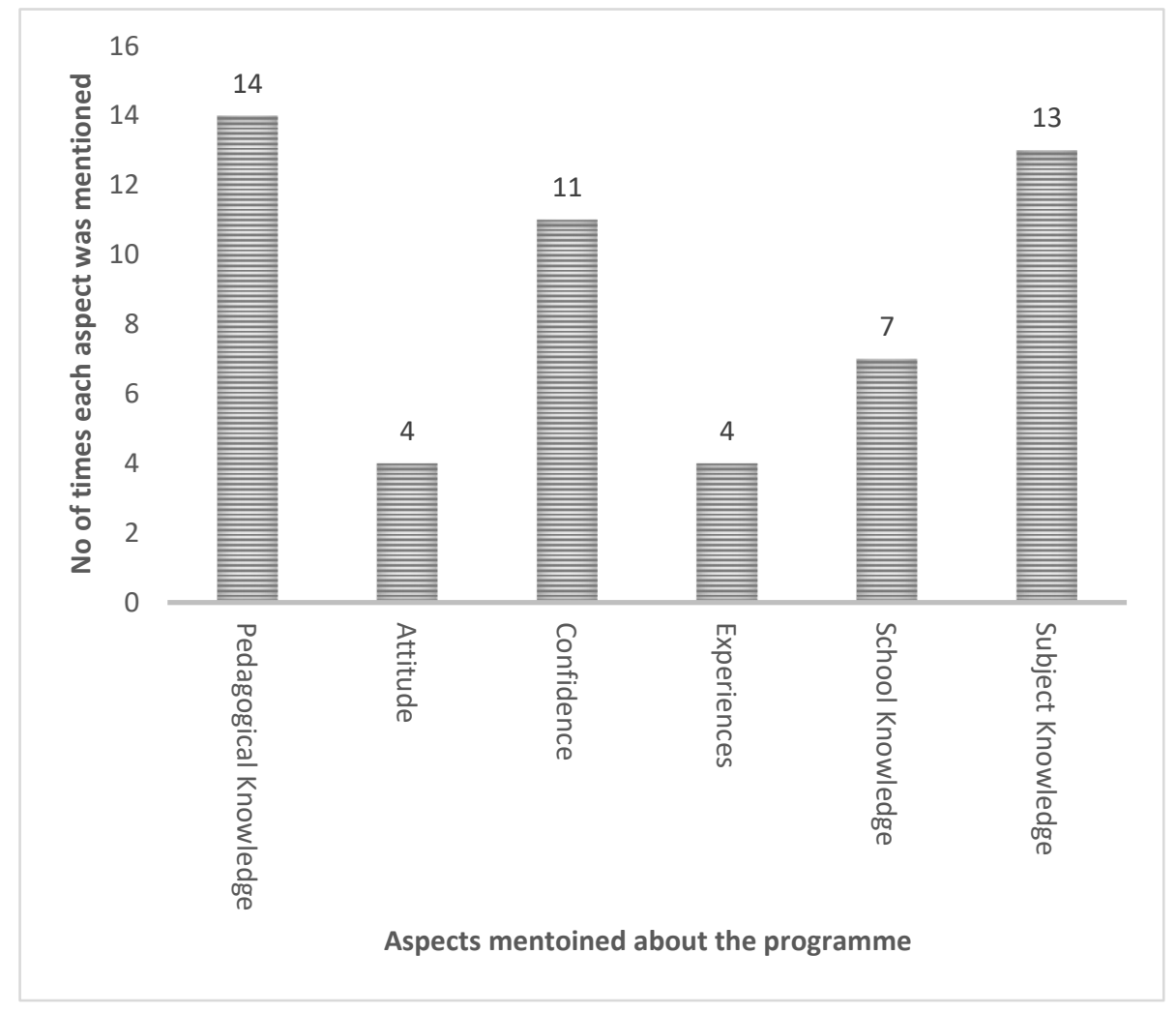

Figure 1 Teachers' experiences of the programme

With regard to their tutors, data from the survey indicate that the teacherstudents valued their own status, with $93 \%$ indicating that tutors treated them as adults or colleagues. This relates to findings by Mukeredzi and Mandrona (2013) who established that student teachers valued being respected, appreciated and acknowledged as colleagues.

The teacher-students (78\%) also praised their tutors for being able to explain content clearly to enhance understanding. While they were generally happy with university support regarding timetables, registration and examination information, assessment and feedback, these ACEPS teacherstudents indicated unhappiness over limited support related to Duly Performed (DP) appeals (37\%) and Special requests (54\%), which were especially 


\section{PS Teachers' Insights into Pedagogical and Content Knowledge}

relevant, given their off-campus study status. Nonetheless, issues around DP are often thorny, even for resident students because few accept an unsatisfactory grade for the final DP mark without an appeal.

With regard to improvement of personal Teaching Practice due to participation in the ACEPS, in the survey, the teacher-students indicated positive outcomes from the programme for three aspects, improved content knowledge (97\%), teaching strategies (88\%), and confidence (89\%).

The interview data were further analysed using Banks et al.'s (1999) model, in order to understand the nature of teacher-students' learning on the programme. Figure 1 shows a summary of the data for the aspects most often mentioned regarding learning and improvement as related to GPK (14), CK (13) and confidence (11). These results affirm the findings from the survey data, where the majority of the teacher-students indicated that participating in the ACEPS programme had improved their content knowledge, teaching strategies and confidence.

\section{Content or Subject Matter Knowledge}

Subject matter knowledge refers to a body of knowledge and information, in a subject or content area, that is taught by teachers and which students are expected to learn. It encompasses the facts, concepts, theories, skills, dispositions and principles that are involved in a specific academic course (Cogill 2008; Shulman 1987; Banks et al. 1999). Thus, CK is the knowledge that teachers should have of the subject matter that they are teaching (Shulman 1987). The argument that the ACEPS students had developed content knowledge over the course of the programme is supported by the following data extracts:

For example if we are talking about zinc powder and zinc lumps, I can easily explain the difference between [the] two to learners because they can physically see it.

I had never done elasticity with my learners before because I never knew it. I didn't even attempt it from the textbook because I never understood it. After doing it in Physics 1A or 1B modules through the programme, I became confident enough to do it on my own in my class. 
The content modules for Physics were very important. For instance, the module we are currently doing had some topics I have never done before (Nuclear Physics and Electricity) and I found it helpful.

My knowledge of Physical Science concepts and content has improved. I am familiar with the content and now find it to be easier to teach than before.

The comments above support McNamara's (1991) claim that teachers with deep CK often teach in a more interesting and dynamic manner than would those with little CK. The latter may shy away from the more difficult concepts of the subject, or approach teaching them in a more didactic manner. McNamara (1991) adds that CK is essential, not only for teaching, but also for evaluating textbooks, computer software and teaching media.

\section{General Pedagogical Knowledge (PK)}

The survey results in Table 1 show that $88 \%$ of the participants considered their teaching strategies to have improved due to the learning on the ACEPS programme. Similarly, in the interviews this domain was mentioned 14 times. Pedagogical knowledge includes elements of pedagogy that are applicable to teachers, regardless of their specialized subject matter knowledge. This kind of knowledge, as Shulman (1987) indicates, is informed by principles of child development and the corresponding approaches to teaching, classroom management, and student control. One teacher-student in the interview pointed out that:

But being a knowledgeable person I am able to use different methods each time I am teaching. For example, there are question and answer methods, and narrative methods. Because I am now confident in the subject, I can vary these and I can deliver better than before.

Such indications that the programme had improved both CK and GPK for teachers may suggest that the main purpose of the programme, improving teacher knowledge, is likely to have been, at least partially, addressed. Further, that the improvement in both participants' CK (97\%) and their PK (88\%) suggests that the teachers had in effect gained PCK, which may be seen as an 
amalgam of the two. This is in accordance with Shulman's (1987) model, where PCK lies at the intersection of CK and GPK and Banks et al.'s (1999) view that PCK involves, not only mastery of school curriculum in a subject, but also teachers creating their own PCK at the intersection of these two 'knowledges'. It would therefore appear that these teacher-students had developed in this aspect. Descriptions offered by participants suggested that the PK that they had gained enhanced their lesson delivery and developed their confidence.

Another important aspect of PK raised by the participants related to the use of media. While this aspect had not come up in the survey, as there had not been a question addressing it, it is highlighted in the interview extract below:

I am now able to present topics well [sic] than before using the apparatus that you provide us. When discussing topics in the classroom I am able to take out the apparatus and show the learners what I am talking about. The learners do not have to imagine what I am talking about they can physically see it.

People learn abstract, new, and novel concepts with more ease when the concepts are presented in both verbal and visual configuration (Bransford, Brown \& Cocking 1999; Willingham 2009). In other words, visual media can make concepts more accessible to learners than text or print media alone. They can also help capture students' attention and maintain their interest, which will assist students with later recall, as reflected in the participant comment below:

We now start with teaching them theory and then do practicals, learners become very excited, and you find that learners are able to remember what they have learnt because of the practicals using the apparatus from the programme.

Apart from helping the teacher to capture students' attention and maintain their interest in the theories and concepts under discussion, students can see theories and concepts in action. In more than a figurative sense, theories and concepts leap from the screen to students' minds (Bransford et al. 1999). Students can experience worlds beyond their own, especially if the media differs sharply from their local environment. As indicated in the comment above, teaching through media then helps them to retain concepts and ideas. 
Furthermore, in the interviews, other teachers talked about their contexts as well as handling learner diversity, for example:

We learn to understand a good teaching environment and the learners we are teaching and it enables us to implement different teaching methods effectively to learners with different learning abilities.

A good teaching environment is one that is conducive to learning and devoid of both physical intimidation and emotional frustration. It thus enables all students to participate and exchange ideas freely.

The aspect of handling learner learning diversity, as mentioned in the comments, is also crucial. Awareness of learner diversity is essential for effective teaching because teachers need to understand that students in a classroom are, and will always be, different from one another in a variety of ways (Ruggs \& Hebl 2012).

Although the in-service teachers talked about their content and pedagogy having improved due to participation in the programme, only $64 \%$ of them agreed that their own learning had improved their learners' performance. Instead, it is noteworthy that about one third of the participants thought that their own learning and development had not translated into improved performance from their learners. This deserves further investigation. Another issue emerging from the survey regards a mismatch between what was taught and what was assessed in the ACEPS programme, in other words the exam questions were perceived to be not closely aligned to the learning guide, which was the set book for the course. When results for disagree and neutral are aggregated, nearly a half $(46 \%)$ of the students indicate that there was no link between the two - what was assessed and what was taught. This is surprising, as students had indicated that they indeed learnt content $(97 \%)$ and pedagogy $(88 \%)$. One is left to wonder how this mismatch could happen, because it was exactly such learning that should have been assessed. To gain further insight, the assessments should be compared with the course content to confirm whether or not there had indeed been a mismatch.

\section{Confidence}

Many students highlighted in their survey responses (89\%) that their confidence had developed through participation in the programme. Likewise, 
in the interviews, confidence was mentioned 11 times as an important aspect where learning had subsequently influenced their teaching, as reflected in the comments below:

I am more confident now. In the past, I use to pay very little attention on some topics because I felt as though they were not important. After gaining more information on these topics from the course I realized how important that they are. Now I am confident to teach these topics to great depth.

It has helped me a lot. I am a lot more confident now than before. There used to be topics I was not clear about but that are not the case anymore. For examples, I am able to teach all topics in the classroom with confidence.

It greatly helped improve my confidence. In order to be confident in teaching you must have knowledge of what you are teaching. Hence, developing knowledge helps develop confidence in the teacher.

Confidence may be viewed as being certain about ones abilities, which is related to self-esteem, and belief in positive achievements and self-awareness about ability to judge one's own performance (Prince, Snowden \& Mathews 2010). From a South Africa study, Graven (2004) concluded that confidence is vital for learning. While the concept of confidence is often understood from a psychological or cognitive viewpoint as being connected to internalized knowledge and beliefs, Graven shows that from a social orientation, confidence is about the ability to engage actively in a teacher community. Growth of confidence was acknowledged by the teachers as emanating from knowledge or ideas that they had gained in the programme, in which they had learnt collaboratively.

The ACEPS teacher-students indicated that they worked in school environments where there was, sadly, limited support with regards to their own learning: only $38 \%$ reported receiving support from school management and only $31 \%$ of the teacher-students felt they had had sufficient time for their studies. Instead, about half the participants (54\%) highlighted the support received from family and colleagues. Support is needed to find balance and to promote academic success. 


\section{Discussion}

\section{What ACE Physical Science Teachers Say that they Learnt through the Programme}

The study investigated the nature of knowledge gained, and support received, on the ACEPS developmental programme. Findings from both survey and interviews indicate that participants gained CK (97\%), PK (88\%), and confidence (89\%). The findings from our study thus support the notion that the objectives of the ACEPS programme had been fulfilled. The programme was intended to develop FET Physical Sciences teachers' CK, PK and practical skills, as well as the necessary PCK. These findings also support those of Mukeredzi (2009), where ACE School Library (ACESL) teacher-students also indicated that they had gained CK and PK.

$\mathrm{CK}$, which is the knowledge of the discipline's main facts, ideas and concepts and the links among them, is vital for effective teaching. Emphasizing its value, Grossman (1990); Chapman (2013); and Mukeredzi and Sibanda (2016) concur that a teacher would find it difficult to judge a given piece of content unless they have good CK. CK affects the way teachers teach, because it influences their planning, choice of learner activities, questioning, explaining, giving feedback, and assessment (Shulman 1987). Content knowledge enables the teacher to use that knowledge and organize it more effectively for their students to understand, he or she can respond to needs of any particular students and recognize those who struggle, and can easily change the way concepts are presented to make them more comprehensible (Hattie 2011). A deep and flexible understanding of subject matter knowledge enables teachers to help their students to create useful cognitive maps, relate ideas, and address misconceptions (Ball, Thames \& Phelps 2008). Teachers need to see how ideas connect across fields and with everyday life. The vital knowledge that teachers need to carry out their teaching work is thus knowledge of the content they teach and what students are expected to master. Hence, teachers need relevant and appropriate CK in order to teach effectively and make appropriate teaching decisions and choices.

Pedagogy is the act of teaching, together with its attendant discourse; it is therefore the knowledge a teacher needs to have and the skills he or she can command to make and justify the decisions, of which teaching is constituted (Leach \& Moon 1999). Pedagogical knowledge therefore pertains to all teachers; regardless of their specialist CK. General pedagogical knowledge is 
vital for effective classroom management. It therefore comprises such aspects as maximising classroom activities and instructional time; directing and pacing learning; understanding learning processes; supporting and fostering individual student progress based on various cognitive and motivational learning strategies; a command of various teaching methods and knowing when and how to use them; understanding forms and purposes of assessments; how different frames (social, individual, criterion-based) impact students' learning; planning and evaluation; structuring objectives and lesson processes; handling classroom diversity and student characteristics (cognitive, motivational, and emotional heterogeneity); use and value of prior knowledge; student motivation (Voss, Kunter \& Baumert 2011). In this study, notwithstanding the gains in $\mathrm{CK}$ and PK, a large group of the teachers (36\%) indicated that their learning had not translated into improved learner performance. Studies in South Africa by Ono and Ferreira (2010) and Graven (2004) concur that most teacher learning programmes have not brought any significant changes in teacher practice and learner performance when the teachers return to their classrooms.

Given the noted gains in CK and PK reported by the in-service teachers studied, and the understanding that PCK is the special amalgam of content and pedagogy required for teaching the subject, these suggests that the teacherstudents also acquired this kind of knowledge. PCK includes understanding of what makes learning of some specific concepts easy or difficult, as well as, for regularly taught topics, the conceptions or preconceptions held by learners of different ages and from different backgrounds and carried into to the learning situation (Ball et al. 2008). This awareness provides teachers with a foundation of how to make concepts accessible to students (Shulman 1987). In addition, PCK bridges knowledge of content and teaching practice, ensuring that content discussions remain relevant to teaching, while discussions of teaching reflect back to content (Ball et al. 2008). It is thus teachers' unique sphere - a contentbased form of professional knowledge which provides an ability to organize and present lessons under the real time constraints of the classroom, allowing for 'deep and integrated understanding' by students (Magnusson, Krajcik \& Borko 2012; Maoto 2014).

Another key issue that emerged from both the survey and the interviews concerned the confidence that the teachers had gained through participation in the programme (89\%). It remains unclear whether development of teacher confidence is peculiar to South Africa, where former apartheid 


\section{Doras Sibanda \& Tabitha Grace Mukeredzi}

education policies had undermined the self-confidence and self-efficacy of the majority of the population (Bertram, Muthiyane \& Mukeredzi 2013). Further, educational reforms since 1994 of introducing a new learner-centred, outcomes-based school curriculum had seemingly placed pressure on teachers and done little to improve their confidence and competences (Graven 2004). Confidence is linked to teacher performance because it increases their motivation, perceptions and thought processes (Prince et al. 2010). More confident teachers, tend to be better at expressing themselves, more daring, take more risks, are more open to learning, and freely seek assistance when they do not understand. These are vital aspects for helping teachers develop reflective practices and so enhance their skills. Teacher confidence influences how students react to teacher instructions and communications (Prince et al. 2010) so teachers' lack confidence may have implications for their teaching practice. This study suggests that many teacher-students gained confidence from studying in the programme. Teacher confidence is embedded in the personal constructs aspects of Banks et al.'s (1999) model, which may be reevaluated throughout a teacher's career. It can be suggested that teacherstudents developed through the programme because of the confidence boost, which may be directly linked to their learning (Graven 2004). The findings of this study clearly show that teacher development programmes should be ongoing in order to promote teacher confidence, among others outcomes. The findings on confidence from the current study are similar to those of Noble (2016) who found that the majority of in-service teachers felt that they were confident to teach science. In the same study, Noble also found that there were fewer teachers who were prepared to teach in the same way as that suggested in the literature. The study by Noble shows that teachers' confidence might improve, but would have limited effect on results in terms of learner achievement. Despite gaining confidence in teaching science, only $64 \%$ of the in-service teachers in the current study agreed that their increased knowledge influenced learner's achievement.

Use of media was another aspect singled out by teacher-students as having benefitted their teaching, because it offers both cognitive and affecttive experiences for the students. Media can be used to provoke discussion and assessment of one's values in scenarios with strong emotional context (Bransford et al. 1999). Media can also be used to develop conceptions through illustrative examples, and, where teachers keep materials and examples up-to-date, it connects students with relevant events. 


\section{Kind of Support ACE Physical Science Teachers Received during the Programme}

With regard to the treatment that students had received from tutors, nearly all (93\%) were satisfied that they had been treated as colleagues; Mukeredzi and Mandrona (2013) had noted a similar finding in their study of student teachers. The teacher-students $(78 \%)$ also appreciated that tutors were able to explain content clearly. However, of concern, was the issue regarding DPs and Special requests. Many ACE teacher-students, whose semester attendance records and class marks were below a certain threshold, indicated that they had received little support from the university in the appeals processes that might have allowed them to sit for final examinations. Only $37 \%$ of respondents had positive experiences with the appeals process, and $54 \%$ felt that the special requests to write examinations had not received a fair hearing. While the guidelines for the specific requirements for each module were available to all students in the university handbook which is also available on-line (University of KwaZulu-Natal (UKZN), 2010), these findings show that these ACEPS teacher-students were not familiar with this information. One could have expected the teacher-students to read the handbook and familiarize themselves with the course requirements. This implies that such information should be incorporated into the module information sheet. Perhaps the teacher-students had not been fully inducted into the university, as would have happened for full-time students, because these mature part-time students had evidently found the whole university experience overwhelming and had not appreciated the formality of all the requirements. They certainly expected, and perhaps needed, more 'babying' than they had experienced.

Meeting the minimum attendance and class mark requirements was problematic for these students, as indicated clearly in the findings. In each of the ACEPS modules, in-order to earn a DP and be allowed to write end-ofsemester examinations, the teachers-students were required to attend $75 \%$ of the lectures or tutorials. The teacher-students were also required to attain at least a $40 \%$ average mark for coursework, which was weighted 50-50 with the examination mark. Given the mixed mode of course delivery, frequently at distant satellite venues, teacher-students were seldom on campus. If they were, it was usually over weekends, when the main university offices were usually closed. Consequently, many of the affected students either did not or could not follow up on these attendance or assessment issues until it was too late. Even 


\section{Doras Sibanda \& Tabitha Grace Mukeredzi}

though the in-service teachers could access the tutors during tutorials and the ACE administrators' offices were usually open during weekend sessions, students often could not attend to DP issues if they did not attend classes. Further, DPs were published only a few days before the end of the teaching period, which left very little time for following up errors or submitting applications to appeal. Thus, DP issues were understandably problematic for the in-service teachers. This raises the issue of whether the reality that these in-service teachers are also full time employees is accounted for in planning the mixed mode of delivery. Keeping the main university offices open over weekends, particularly during the period preceding examinations could help students address such issues.

Despite students having indicated learning from the programme, what also emerged was that these the ACE in-service teachers worked in school environments that did not support their learning. Only $54 \%$ received family support, $38 \%$ received support from their schools and only $31 \%$ indicated that they had enough study time. These finding are in contrast to recommendations in the literature about the support that teacher get from their families, and work places (Resnick et al. 1997; Schaps, Battistich \& Solomon 1997). A substantial body of research shows that, for good or ill, a school's social environment has a strong influence on learning and growth, including social, emotional, and ethical development for teachers (Schaps et al. 1997). This makes us wonder how the in-service teachers succeed at all whilst working under such unsupportive conditions. Perhaps more important than management support in the school environment is the quality of relationships teacher-students had with their students and colleagues. As John Dewey (1958: 65) observed, an effective school 'is realized to the degree in which individuals form a group'. Often when staff find their school environment supportive and caring, they are likely to become involved in activities that support their work. Accordingly, they would be more likely to develop positive attitudes toward their learners, their teaching, and themselves, and to have pro-social attitudes and behaviors toward colleagues (Schaps et al. 1997). Many schools foster positive learner outcomes by promoting a sense of 'connectedness' or 'belongingness' (Baumeister \& Leary 1995), or 'community' (Schaps et al. 1997) during the school day. Of the teacher-students in this study, only $38 \%$ had had support from colleagues. This was probably the key finding. Connectedness, belongingness, and community all refer to staff and students' sense of being 'in-close', with respectful relationships among colleagues and students in a school. 
Other aspects that also emerged from the data related to the in-service teachers having developed skills in creating conducive classroom environments, which are often regarded as catalysts for effective teaching, student learning and handling learner diversity. Spencer (2003) indicates that effective teachers understand and develop a positive climate in the learning environment, and use appropriate methods and language for all students to understand. Awareness of students' learning diversity requires exploring their differences in a safe, positive, and nurturing environment, understanding each individual, going beyond simple tolerance to embracing and celebrate the rich dimensions of their diversity (Ruggs \& Hebl 2012).

\section{Conclusion}

The main aim of this study was to understand the nature of support and the knowledge that the teacher-students gained in the ACEPS programme. The findings suggest that the professional developmental programme provided sufficient support for students to improve their CK (97\%), GPK (88\%), and confidence levels (89\%). More than half of the participants indicated that their improved learning had translated into learner achievement, but a third of the teacher-students were not sure about this aspect. A high number of teacherstudents identified general areas of concern about the level of support they received from the university, in particular the processes involving examinations that appeared unclear for off-campus students. However, as this was a small study, these findings would need confirmation through a more comprehensive research or a larger scale survey. Given that only eight teacherstudents were interviewed, more light could also be shed through interviews with a larger sample, to understand teacher-students' views about how they attempt to improve student learning through applying their improved content knowledge, confidence and teaching strategies. Although the findings should not be generalized as this was a convenience sample, they do highlight that teacher content knowledge and confidence can improve through professional development programmes. Overall, the findings from this study reinforce the need for institutions of higher learning to consider designing programmes that provide appropriate levels of support for all students. 


\section{Acknowledgements}

We acknowledge the support by the UKZN Teaching and Learning Office in funding the project, Exploring the Impact of the ACE Programme, on which the paper is based.

\section{References}

Aluko, R.F. 2009. The Impact of an Advanced Certificate in Education (ACE) Program on the Professional Practice of Graduates. International Review of Research in Open and Distributed Learning 10,4: 1 - 25.

Ball, D.L., M.H. Thames \& G. Phelps 2008. Content Knowledge for Teaching: What Makes it Special? Journal of Teacher Education 59,5: 389-407 https://doi.org/10.1177/0022487108324554

Banks, F., J. Leach \& B. Moon 1999. New Understandings of Teachers' Pedagogic Knowledge. In Leach, J. \& B. Moon (eds.): Learners and Pedagogy. London: Paul Chapman Publications.

Baumeister, R.F. \& M.R. Leary 1995. The Need to Belong: Desire for Interpersonal Attachments as a Fundamental Human Motivation. Psychological Bulletin 117: 497 - 529. https://doi.org/doi:10.1037/0033-2909.117.3.497

Bernstein, A. (series ed.). 2011. Value in the Classroom: The Quantity and Quality of South Africa's Teachers. Johannesburg: Centre for Development and Enterprise (CDE). Available at:

http://www.cde.org.za/wp-

content/uploads/2012/12/VALUE_IN_THE_CLASSROOM_full_report. pdf

Bertram, C., N. Mthiyane \& T.G. Mukeredzi 2013. 'It will make me a real teacher': Learning Experiences of Part-time PGCE Students in South Africa. International Journal of Educational Development, 33,5: 448 456. https://doi.org/10.1016/j.ijedudev.2012.10.001

Bransford, J.D., A.L. Brown \& R.R. Cocking (eds.) 1999. How People Learn: Brain, Mind, Experience, and School. Washington, DC: National Academy Press.

Chapman, O. 2013. Investigating Teachers' Knowledge for Teaching Mathematics. Journal of Mathematics Teacher Education 16,4: 237 - 243. Available at: 
https://search.yahoo.com/yhs/search?hspart=iba\&hsimp=yhs-

1\&type=gpnt_7571_CHW_ZA\&p=10.1007\%2Fs10857-013-9247-2

DOI: $10.1007 / \mathrm{s} 10857-013-9247-2$

Cogill, J. 2008. Primary Teachers' Interactive Whiteboard Practice across

One Year: Changes in Pedagogy and Influencing Factors. Unpublished

Ed.D. Thesis, King's College, University of London. Retrieved from:

www.juliecogill.com

Council on Higher Education. 2010. Report on the National Review of Academic and Professional Programmes in Education. Pretoria. HE Monitor 11 (August 2010).

Creswell, J.W. 2014. Research Design: Qualitative, Quantitative and Mixed Methods Approaches. ${ }^{\text {th }}$ Edition. Thousand Oaks, CA: Sage Publications. Department of Education 2006. The National Policy Framework for Teacher Education and Development in South Africa. Pretoria: Department of Education.

Department of Higher Education and Training (DHET) Report Vote 15 Annual financial year 2015/2016. Available at:

http://www.dhet.gov.za/Commissions\%20Reports/DHET\%20Annual\%2

0Report\%202015-2016.pdf

Dewey, J. 1958. Experience and Nature. Mineola NY: Dover.

Grossman, P. 1990. The Making of a Teacher. Teacher Knowledge and

Teacher Education. New York \& London: Teachers College Press.

Graven, M. 2004. Investigating Mathematics Teacher Learning within an

In-service Community of Practice: The Centrality of Confidence. Educational Studies in Mathematics 57: 177 - 211.

https://doi.org/10.1023/B:EDUC.0000049277.40453.4b

Grover, S. 2004. Why won't they listen to us? On Giving Power and Voice to Children Participating in Social Research. Childhood 11,1 81 - 93. https://doi.org/10.1177/0907568204040186

Hattie, J.A.C. 2011. Which Strategies Best Enhance Teaching and Learning in Higher Education? In Mashek, D. \& E. Hammer (ed.): Empirical Research in Teaching and Learning: Contributions from Social Psychology. Chichester: Wiley-Blackwell.

https://doi.org/10.1002/9781444395341.ch8

Leach, J. \& Moon, B. 1999 Recreating Pedagogy. In Leach, J. \& B. Moon (eds.): Learners and Pedagogy. London: Paul Chapman.

McNamara, D. 1991. Subject Knowledge and its Application: Problems and 
Possibilities for Teacher Educators. Journal of Education for Teaching

17,2: 113 - 128. https://doi.org/10.1080/0260747910170201

Magnusson, S., J. Krajcik \& H. Borko 2012. Nature, Sources and Development of Pedagogical Content Knowledge for Science Teaching. In GessNewsome, J. \& N.G. Lederman (eds.): Examining Pedagogical Content Knowledge: The Construct and its Implications for Science Education.

Dordrecht, The Netherlands: Kluwer Academic.

Mahlangu V.P. \& V.J. Pitsoe 2013. The Changing Landscape in the Conditions of Service for Teachers in South Africa. Journal of Social Science 36,1: 69

- 75. Available at: http://hdl.handle.net/2263/40934

Maoto, S. 2014. Creating a Conducive Environment for Mathematics Teacher Learning. Journal for Education Studies 13,2: 21 - 41.

Mukeredzi, T.G. \& A. Mandrona 2013. The Journey to Becoming Professionals: Student Teachers' Experiences of Teaching Practice in a Rural South African Context. International Journal of Educational Research 62: 141 - 151. https://doi.org/10.1016/j.ijer.2013.07.010

Mukeredzi, T. \& D. Sibanda 2016. Part-Time Post Graduate Certificate in Education Teacher-Students: What do they Bring to and Expect from a Formal South African Teaching Programme? Australian Journal of Teacher Education 41,9: 81 - 99.

https://doi.org/10.14221/ajte.2016v41n9.5

Ono, Y. \& J. Ferreira 2010. A Case Study of Continuing Teacher Professional Development through Lesson Study in South Africa. South African Journal of Education 30: 59 - 74.

Parker, B. 2004. Roles, Responsibilities, Institutional Landscapes and Curriculum Mindscapes: A Partial View of Teacher Education Policy in South Africa: 1999 - 2000. In Lewin, K., M. Samuel \& Y. Sayed (eds.): Changing Patterns of Teacher Education in South Africa. Johannesburg: Heinemann.

Prince, T., E. Snowden \& B. Matthews 2010. Utilising Peer Coaching as a Tool to Improve Student - Teacher Confidence and Support the Development of Classroom Practice. Literacy Information and Computer Education Journal 1,1: 49 - 51. https://doi.org/10.20533/licej.2040.2589.2010.0007

Noble, M.K. 2016. Science Teacher Confidence. Science Journal of Education 4,1: 8 - 13. https://doi.org/10.11648/j.sjedu.20160401.12

Reeves, T.C. \& J.C. Hedberg 2003. Interactive Learning Systems Evaluation. Englewood Cliffs, New Jersey: Educational Technology Publications. 
Resnick, M.D., P.S. Bearman, R.W. Blum, K.E. Bauman, K.M. Harris, J. Jones, J. Tabor, T. Beuhring, R.E. Sieving, M. Shew, M. Ireland, L. H. Bearinger \& J.R. Udry 1997. Protecting Adolescents from Harm: Findings from the National Longitudinal Study on Adolescent Health. Journal of the American Medical Association 278,10: 823 - 832.

https://doi.org/10.1001/jama.1997.03550100049038

https://doi.org/10.1001/jama.278.10.823

Robinson, B. \& C. Latchem (eds.) 2002. Teacher Education through Open and Distance Learning. London: Routledge.

Ruggs, E. \& M. Hebl 2012. Diversity, Inclusion, and Cultural Awareness for Classroom and Outreach Education. In Bogue, B. \& E. Cady (eds.): Apply Research to Practice (ARP) Resources. Available at:

http://www.engr.psu.edu/AWE/ARPResources.asp

Sai. L. 2008. Teaching Knowledge, Work-based Learning and Life Experiences. Paper presented at the British Educational Research Association Annual Conference, Heriot-Watt University, Edinburgh, 3-6 September 2008.

Schaps, E., V. Battistich \& D. Solomon 1997. School as a Caring Community: A Key to Character. In Molnar, A. (ed.): The Construction of Children's Character. Ninety-sixth Yearbook of the National Society for the Study of Education. Chicago: National Society for the Study of Education.

Shulman, L. 1987. Knowledge and Teaching: Foundations of the New Reform. Harvard Educational Review 57,1: 1 - 22.

https://doi.org/10.17763/haer.57.1.j463w79r56455411

Spaull, N. 2013. Poverty \& Privilege: Primary School Inequality in South Africa. International Journal of Educational Development 33: 436 - 447. https://doi.org/10.1016/j.ijedudev.2012.09.009

Spencer, J. 2003 Learning and Teaching in the Clinical Environment. In Cantillon, P., L. Hutchinson \& D. Wood (eds.): BMJ ABC of Learning and Teaching in Medicine. London: BMJ Publishing Group.

Stears, M., A. James \& M. Good 2012. Exploring the Professional Identities of Physical Science Teachers Enrolled in an Advanced Certificate in an Education Programme. Education as Change 16,2: 241 - 253.

Taylor, N. 2009. The State of South African Schools. Part 1: Time and Regulation of Consciousness. Journal of Education 46,10: 9 - 32. https://doi.org/10.1080/16823206.2012.745753 
Voss, T., M. Kunter \& J. Baumert 2011. Assessing Teacher Candidates' General Pedagogical/ Psychological Knowledge: Test Construction and Validation. Journal of Educational Psychology 103: 952 - 969. https://doi.org/10.1037/a0025125

Willingham, D.T. 2009. Why Don't Students Like School: Because the Mind is not Designed for Thinking. American Educator Spring: 4 - 13.

Doras Sibanda

School of Education

Pietermaritzburg Campus University of KwaZulu-Natal

Sibandad@ukzn.ac.za

Tabitha Grace Mukeredzi Adult Education Unit Faculty of Arts and Design Durban University of Technology Midlands Campus Pietermaritzburg, TabithaM@dut.ac.za 